\title{
MAP OF GLACIAL STRIATION OF THE SCANDINAVIAN ICE SHEET DURING THE LAST (WEICHSEL) GLACIATION IN NORTHERN EUROPE
}

\author{
GunNar Glückert
}

\begin{abstract}
GlüCKert, GunNar 1974: Map of glacial striation of the Scandinavian ice sheet during the last (Weichsel) glaciation in northern Europe. Bull. Geol. Soc.

Finland $46,1-8$.
\end{abstract}

\begin{abstract}
The observations on glacial striae from the area of the Scandinavian ice sheet have been collected from previous Danish, Norwegian, Swedish and Finnish geological literature. The main directions of ice movement of the Weichsel glaciation in northern Europe have been compiled by the author on a map (Appendix I) and shortly explained in this paper. In several closelystudied small areas there can be distinguished two or more successive generations of striae, representing different directions of ice flow during the Weichsel glaciation. The clusters of arrows on the map in Fig. 1 show the relative ages of several ice movements. These are mostly only local, and cannot be generalized over the whole of Fennoscandia. There are also still many areas for which no investigations of striation exist.
\end{abstract}

Gunnar Gluickert, Institute of Quaternary Geology, University of Turku, 20500 Turku 50, Finland.

\section{Introduction}

The purpose of this paper was to collect all the observations on striae from the center parts of the Scandinavian ice sheet during the last Weichsel/Würm glaciation and compile the main directions of striae on a coherent map (Appendix I). An attemp has been made to reconstruct the main directions of movement of relative ages of the ice sheet by means of observations on striae compiled from previous Scandinavian and Finnish geological literature (Fig. 1).
The material of this map on striation is based on glacial maps of Holtedahl (1960) and G. Lundqvist (1954) and on map references from several Finnish geological sources. Holtedahl (1960) has published the »Glacial map of Norway» and G. Lundqvist (1954) the map of »Glacial striae» of Sweden. These maps are copied in Appendix I and contain a representative selection of observations on striations of the whole of both countries (Appendix I).

The first map on striation in Finland was published by Nordenskiöld in 1863 and contained 


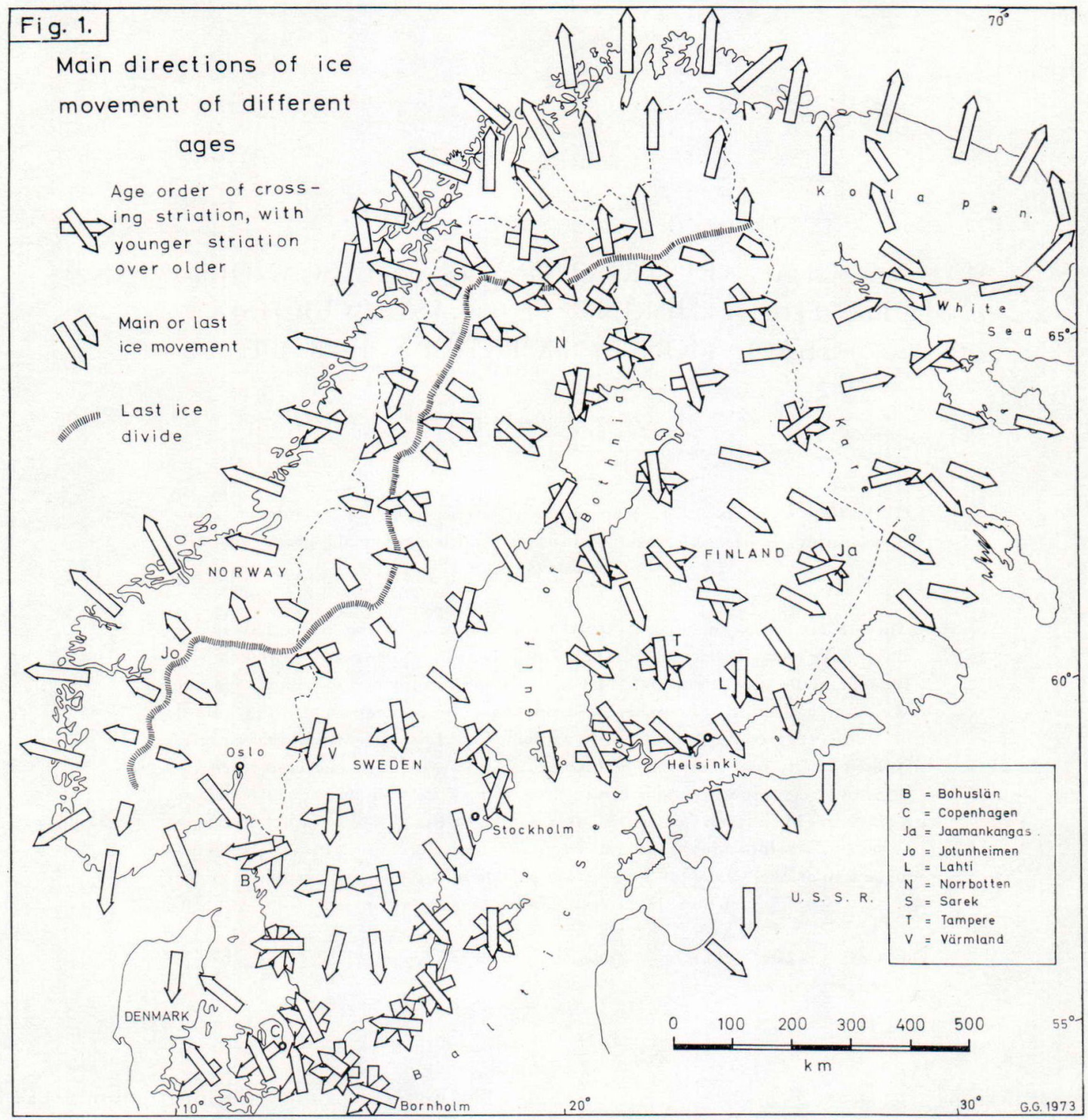

500 observations on striae from southern and central Finland. Since this classic study no general map of glacial striae with so many observations from the whole of the country has been compiled and published. That is why the author had to collect the directions of ice flow from previous glacial geological maps and publications which deal with relatively small areas in Finland. All these sources for this study have been referred in the bibliography.
The compilation of striation by the author is the first collection of striae from the whole of Fennoscandia (Norway, Sweden and Finland), connected with adjointing areas: the Kola peninsula, the surroundings of the White Sea, Karelia and the Baltic countries in the U.S.S.R., and Denmark. The map (Appendix I) shows a representative and generalized selection of the observations on striae, indicating the main different directions of ice flow. According to the striation, 
the supposed position of the main ice shed during the last phase of Weichsel glaciation has been drawn on the map. No results of till fabric analyses were used to study the directions of ice flow in Fennoscandia.

Only a few geological publications about northern Russia, Karelia and the Baltic countries were available to the author. Besides, outcrops of bedrock are very scarce in some places for these areas. This is why there are very few observations on striae on the map for these areas (Appendix I).

The striae indicate in general the directions of ice movement, at least of the last or strongest one. The striae are not of the same age, but often get younger towards the ice center. In many places there are two or more generations, representing different directions of ice movement. In favourable cases it is possible to determine their relative ages within a relatively small area.

Fig. 1 shows the main directions of flow of relative ages from several areas studied in detail. The directions of various ages are thus mostly only local, and can be compared with each other only within relatively small areas: e.g. two areas in Sweden and Finland with several directions of relative ages (younger striation over older in Fig. 1) cannot be placed on a level with each other. There are still areas for which no investigations of striae exist. Thus the Fig. 1 still gives rather an unsatisfactory and unhomogeneous picture of the directions of relative ages in Fennoscandia. The material used for this map is inadequate to explain the relative ages all over the area of the ice sheet.

\section{Directions of ice flow}

The whole of Fennoscandia, with adjacent parts of northern European Russia, Poland, the German countries, and Denmark, were covered by the ice of the Scandinavian ice sheet at Weichsel glaciation. According to the evidence of cirques, erratic boulders, and glacial striae, the last glaciation had its origin in the mountains of Scandinavia. The increasing ice masses gradually expanded into extended piedmont glacier lobes and spread over the whole northern part of the continent. At various times during the Weichsel glaciation there were differences in the extent of the ice. In the early Weichsel period, at the clacial maximum, the area of the ice sheet was greater than that of its late Weichselian successor.

The various directions of striae in northern Sweden and along the Swedish-Norwegian border indicate that there was an ice divide or several divides that shifted their positions during the glaciation.

The ice divide, indicated on the maps (Fig. 1 and Appendix I), is based on the striation belonging mostly to late Weichselian main directions of ice moving (G. Lundqvist 1954). This ice shed is not synchronous in all its run, and does not represent the real glacial circumstances. Local differences in ice flow, strongly depending on the topography, are quite noticeable. These local striae do not correspond to the main directions but belong to local small glacier advances during the last active phases of deglaciation (see also Ljungner 1943, 1945).

The accumulation of ice east of the mountain crest implies shifting of the ice sheds. In the course of glaciation the center of radial outflow of the ice (the ice culmination) moved from the mountain crest eastwards towards the Gulf of Bothnia, and with it the main ice divide. At the glacial maximum the ice divide and the thickest parts of the ice body were probably situated in the area slightly west of the Gulf of Bothnia, or the center of the postglacial uplift of land. At the late glaciation period the ice shed moved westwards, back to the mountains (Hoppe and Liljequist 1956 pp. $45-50$ and $71-73$ ).

The Sarek region in northern Sweden, with several recent glaciers, was a late centre of glacial activity during the final phase of glaciation. The Sarek and Jotunheimen uplands in the mountain range were probablv the two main 
centres of accumulation and outflow of ice during Weichsel glaciation (Hoppe and Liljequist 1956 pp. 50 and 73) (Fig. 1).

In the mountains and coastal regions of Norway, local movements of ice took place in all directions. Thus the great influence of local topographical differences in elevation on the variations on striation is to be noticed. In general a radial outflow of ice from the main ice divide took place in the mountain range. From the main ice shed lying on the Swedish side of the mountains, the ice in general flowed mainly towards the Norwegian coast (Fig. 1 and Appendix I).

According to Bøggild (1896) and Holmström (1904 pp. 299-304) the northerly and northeasterly directions of ice movement on the island of Bornholm in the southern part of the Baltic Sea were older than the southeasterly flow. In Denmark only a few outcrops of the deeplying bedrock with glacial exaration marks occur. The striae from the SE of the youngest Baltic ice S and SW of Copenhagen cross the older directions from the NE and E (Bøggild 1896 and Holmström 1904 pp. 304-309; see also Rasmussen 1968 p. 81) (Fig. 1 and Appendix I).

Holmström (1904) has compiled from older sources several separate generations of ice flow in southern Sweden: the older Baltic ice from the $\mathrm{SE}-\mathrm{E}$, the Meridian ice from $\mathrm{N}-\mathrm{NW}$, and the two young Baltic ice flows from the $\mathrm{N}-\mathrm{NE}$ and $\mathrm{SE}-\mathrm{S}$. The younger one of these Baltic ice flows took place just before the beginning of the deglaciation period and was characterized by many oscillations. The striae belonging to the last ice movements during deglaciation came from the NE-N. All of these main Weichselian ice flows are not known in the other parts of Sweden.

On the western coast of southern Sweden (Bohuslän) some observations of the old northwesterly and northerly striations exist. The main direction of movement of the ice was from NE, and the youngest show an almost westerly trend.
In western central Sweden (Värmland) the northeasterly striae are older than the northerly ones (G. Lundqvist 1954) (Fig. 1).

On the eastern coast of Sweden, $\mathrm{N}$ of Stockholm, the main northwesterly striae are crossing by the youngest striation of the Bothnian ice from the NNE. Along the coastal areas of the Gulf of Bothnia and the Baltic Sea there are a lot of striae representing the youngest ice movement from the N-NNE, and on the Finnish side of the gulf, from N-NNW (Fig. 1).

In Norrbotten, northern Sweden, beneath the last ice divide, quite a complicated system of different directions of ice movement can be observed. The relations from older to younger are NNW - WNW, W - NW, N (G. Lundqvist 1943, 1954, and J. Lundqvist 1971) (Fig. 1).

In southern and western Finland the oldest direction of ice movement seems to have been from the west (e.g. Helaakoski 1940, V. Okko 1949, Virkkala 1962 and Glückert 1971). This movement probably took place at the glacial maximum during the early Weichsel glaciation. Later, during the last advance of the ice, the dominant direction in south and central Finland was towards the SE-SSE, in southern Lapland (northern Finland) towards the SE-E, and in northern Lapland, on the other side of the ice divide, towards the NE-N-NW (e.g. Tanner 1915 and V. Okko 1964) (Appendix I).

During the final stages of retreat, the ice was strongly influenced by climatic changes and the topography. Some oscillations of ice took place as advances in several areas in southern and central Finland. The positions of the three Salpausselkä ice marginal formations in southern Finland show an advance and stagnation of ice during deglaciation. At Lahti, north of Helsinki, the movements of ice came from the $\mathrm{N}$ and NNE during the Salpausselkä stage (e.g. M. Okko 1962) (Fig. 2).

In central Finland, during deglaciation after the Salpausselkä stage, the ice made another slight advance towards the $\mathrm{S}$ and SE in the regions of Tampere and Jyväskylä. During this 


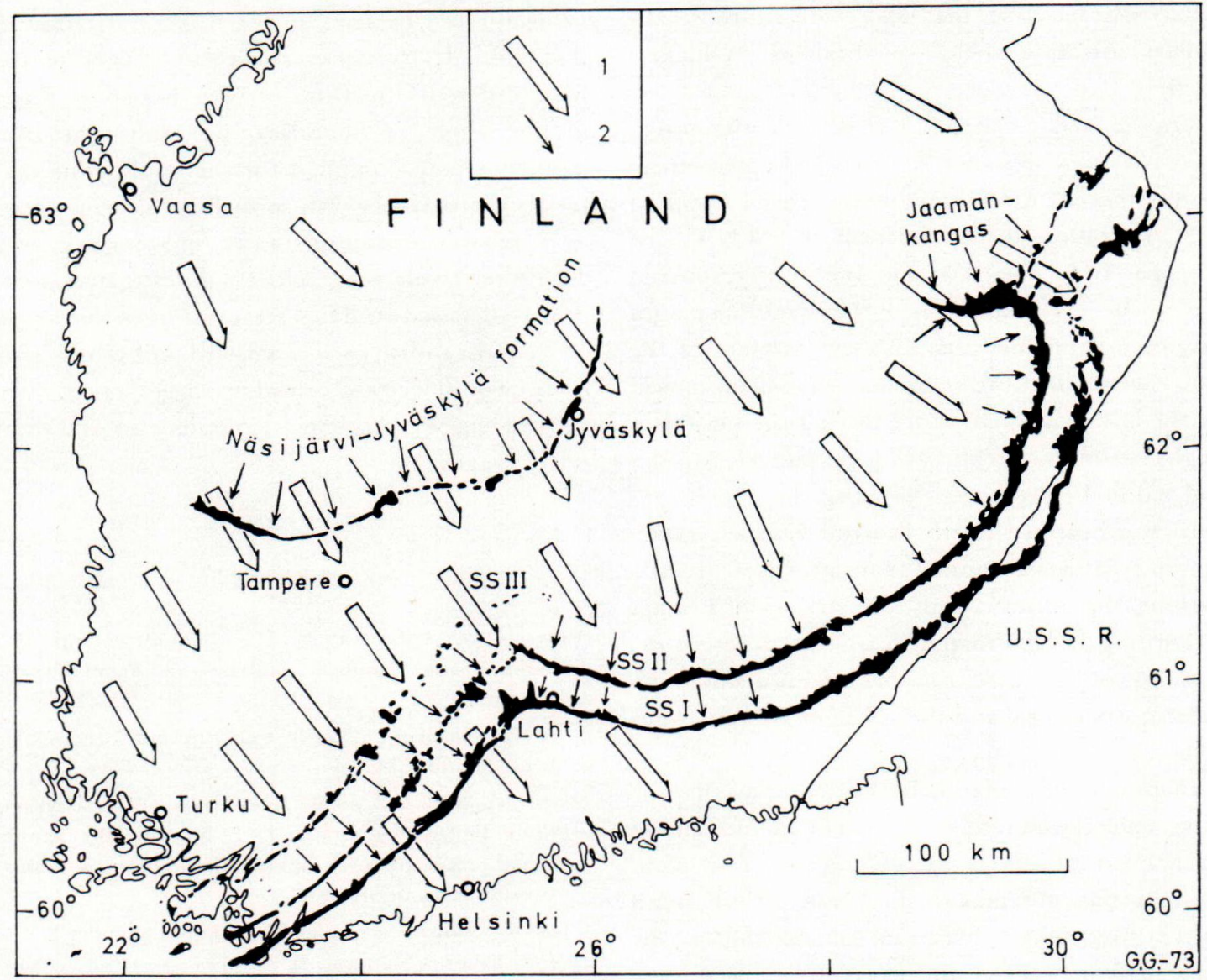

Fig. 2. The three Salpausselkä systems, SS I, SS II and SS III, aswell the Näsijärvi-Jyväskylä, and the Jaamankangas ice marginal formations were formed by local advances and stagnation of the ice during general deglacia tion. 1 = general trend of ice movement, 2 = youngest ice movements (local advances) during deglaciation.

stagnation the glacier formed the ice marginal formation of central Finland, also called the Näsijärvi-Jyväskylä end moraine (e.g. Virkkala 1962 pp. 58-66, Repo 1964 and Aartolahti 1972) (Fig. 2).

On the basis of the crossing striae the earliest glacier movement in the Tampere region took place from the west. However, the most prevalent and strongest striation indicates an advance of the ice from the NW. The last glacier movements came from the $\mathrm{N}$ and NNE. Some striae also show a movement occuring from the $\mathrm{W}$ and SW (Virkkala 1962 pp. 62-63; see also Flint 1971 p. 94) (Fig. 1 and 2).
The formation of Jaamankangas in the eastern central Finland belongs to the Salpausselkä system. In that region the two older directions of striae indicate an ice flow from the NNW and NW. The youngest directions come from the W-SW and NW. On the basis of an analysis of glacial striae Repo (1957 pp. 166-167) interprets the Jaamankangas as a terminal formation of two different ice lobes that moved at right angles towards each other, from W-SW and N-NW (see also Repo 1969 pp. 74-75) (Fig. 2).

In central Finland one's attention is caught by the fanshaped orientation of striation. This area was occupied by a strongly advancing Weich- 
selian glacier lobe that also formed there the largest drumlin field in Finland (Glückert 1973).

On the coast of the Gulf of Bothnia the movement of Weichselian ice flows took place from three different directions. These are in order of age: the oldest direction from the WNW, the younger from the NW and the youngest from the NNW-N. The traces of the two older stages originate from the most effective activity of the ice, whereas the third stage may have been caused by the last movement of ice during the period of deglaciation (V. Okko 1949 p. 13 and 47; Mölder and Salmi 1954 pp. 97-98) (Fig. 1).

In southeastern north Finland Korpela (1969 pp. 76-78) has compiled from previous investigations the observations on striae on a map. According to this map at least two different directions of ice flow can be distinguished: the older nortwesterly and the younger westerly ones (Fig. 1).

In northern Lapland, beyond the last ice divide, several different directions of ice movement have been observed by geologists. The main young striation seems to show a N-NNE trend of ice flow. Older directions of moving can be noticed from the $\mathrm{W}$ and even from the $\mathrm{E}$ (e.g. Tanner 1915) (Fig. 1).

In the coastal regions of the Arctic ocean and the Kola peninsula, Ramsay $(1900,1912)$ and Tanner (1915), among others, have tried to clear up the different directions of glacier movement. Ramsay (1912 pp. 12-14) has separated four different directions of ice that flowed over the Kola peninsula in the northern U.S.S.R. In Karelia, U.S.S.R., SW of the White Sea, Rosberg (1892) separates two directions of ice flow. The younger westerly one crosses the older ice flow from the NW (Fig. 1 and Appendix I).

\section{Conclusions}

The main trend of the last or strongest movements of the ice, and of other directions of va- rious age can be seen on the map of striation in Appendix I. However, the relative ages of the main different directions of Weichselian ice flows in the whole of Fennoscandia cannot be seen from this map compiled for the study. The material of crossing striation in Fig. 1 can be used as a reliable indicator of ice movements only within relatively small, closely investigated areas. A very detailed study of striation over the whole of Fennoscandia, connected with till fabric analyses, would certainly lead to more exactly results of the Weichselian ice movements and their relative ages.

\section{REFERENCES}

Aartolahtr, Tolve (1968) Die Geomorphologie des Gebiets von Tammela, Südfinnland. Fennia 97, 7, $97 \mathrm{p}$.

- (1972) On deglaciation in southern and western Finland. Fennia 114, 84 p.

Berghell, Hugo (1904) Geologisk öfversiktskarta öfver Finland. Sektionen D 2, Nyslott. Beskrifning till jordartskartan. Résumé. Geologiska Kommissionen, Helsingfors, 136 p.

- (1927) Suomen geologinen yleiskartta. Lehdet E 2 ja E 3, Salmi ja Suojärvi. Selitys maalajikarttoihin. Suomen Geologinen toimikunta, 147 p.

Brander, G. (1934) Suomen geologinen yleiskartta. Lehti C 3, Kuopio. Maalajikartan selitys. Suomen geologinen toimikunta, $67 \mathrm{p}$.

BøgGILD, O. B. (1896) Om Skurestriber i Danmark og beslaegtede Faenomener. Meddelelser fra Dansk Geologisk Forening Nr. 3, pp. 73-104.

Edelman, N. (1951) Glacial abrasion and ice movement in the area of Rosala-Nötö, S. W. Finland. Bulletin de la Commission géologique de Finlande 154, pp. 157-169.

Flint, Richard Foster (1971) Glacial and Quaternary geology, New York, 892 p.

Fogelber G, Paul (1970) Geomorphology and deglaciation at the second Salpausselkä between Vääksy and Vierumäki, southern Finland. Societas Scientiarum Fennica. Commentationes Physico-Mathematicae 39, $90 \mathrm{p}$.

Frosterus, Benj. (1913) Suomen geologinen yleiskartta. Lehti C 2, Mikkeli. Maalajikartan selitys. Geologinen toimisto, $49 \mathrm{p}$. 
GlüCkert, GunNar (1971) Bewegungen des Inlandeises im Lohja-Seebecken, Südfinnland. Bulletin of the Geological Society of Finland 43, pp. 173-184.

- (1973) Two large drumlin fields in central Finland. Fennia 120,37 p.

Hausen, H. (1913) Materialien zur Kenntnis der Pleistozänen Bildungen in den russischen Ostseeländern. Fennia 34, 2, 181 p.

Hela koski, A. R. (1940) Mannerjäätikön liikuntosuunnista Pohjanmaan rannikolla ja Tampereen ympäristössä. Referat: Über die Bewegungsrichtungen des Inlandeises an der Küste von Pohjanmaa und in der Umgebung von Tampere. Fennia 67, 1, 36 p.

Holmström, LeONARD (1904) Öfversikt af den glaciala afslipningen i Sydskandinavien. Geologiska Föreningen i Stockholm Förhandlingar 26, 4, pp. 241316.

Holtedahl, Olaf (1960) Geology of Norway. Glacial map of Norway 1:2000 000. Norges Geologiske Undersøkelse Nr. 208, 540 p.

Hoppe, Gunnar and Gösta H. Liljequist (1956) Det sista nedisningsförloppet i Nordeuropa och dess meteorologiska bakgrund. Summary: The course of the last glaciation in northern Europe and its meteorological background. Ymer 77, 1, pp. $43-74$.

Hyyppä, EsA (1948) Tracing the source of the PyriteStones from Vihanti on the basis of Glacial geology. Bulletin de la Commission géologique de Finlande 142, pp. $97-122$.

- (1950) Helsingin ympäristö. Maaperäkartan selitys. Geologinen tutkimuslaitos, 53 p.

JAATINEN, Stig (1960) The glacial morphology of Aland, with special reference to the Quaternary deposits. Les formes glaciaires de I'ile Åland. Fennia 84, 1 , pp. $5-38$.

Kertomus karttalehtiin No:t 1, 4, 7, 8, 10, 11, 12, 14 , $15,16,17,18,19,21,22,23,24,25,26,27,28,32$, $33,34,35,37$. Suomen geologinen tutkimus. Finlands geologiska undersökning, $1884-1900$.

KILPI, SAMPO (1937) Das Sotkamo-Gebiet in spätglazialer Zeit. Bulletin de la Commission géologique de Finlande 117,118 p.

Korpela, Kauko (1969) Die Weichsel-Eiszeit und ihr Interstadial in Peräpohjola (Nördliches Nordfinnland) im Licht von submoränen Sedimenten. Annales Academiae Scientiarum Fennicae Ser. A. III, 99, 107 p.

Kujansuu, Raimo (1967) On the deglaciation of Western Finnish Lapland. Bulletin de la Commission géologique de Finlande 232, 98 p.
LJUNGNER, ERIK (1943) Isdelarstudier vid polcirkeln. Zusammenfassung. Eisscheidenstudien am nördlichen Polarkreis. Geologiska Föreningen i Stockholm Förhandlingar 65,2 , pp. 198-210.

- (1945) Den sista nordiska nedisningens förlopp. Zusammenfassung. Verlauf der letzten nordischen Vereisung. Geologiska Föreningen i Stockholm Förhandlingar 67,2 , pp. 225-240.

Lundevist, G. (1943) Norrlands jordarter. Sveriges Geologiska Undersökning, Ser. C, Nr. 457, $166 \mathrm{p}$.

- (1954) Atlas över Sverige; 21-22, Geologi: Räfflor, ändmoräner och isrecessionslinjer. Atlas of Sweden, 21-22, Geology: Glacial striae, terminal moraines and lines of ice recession. Stockholm.

LUNDQVIST, JAN (1971) The interglacial deposit at the Leveäniemi mine, Svappavaara, Swedish Lapland. Sveriges Geologiska Undersökning, Ser. C, Nr. 658, $166 \mathrm{p}$.

Mölder, Karl (1948) Die Verbreitung der Dacitblöcke in der Moräne in der Umgebung des Sees Lappajärvi. Bulletin de la Commission géologique de Finlande 142 , pp. $45-52$.

Mölder, K. and Martit SALMi (1954) The general geological map of Finland. Sheet B 3, Vaasa. Explanation to the map of superficial deposits. The Geological Survey of Finland, 109 p.

NordenskiöLd, N. (1863) Beiträge zur Kenntnis der Schrammen in Finnland. Acta Societatis Scientiarum Fennicae 7, pp. 505-543.

Okno, Marjatta (1962) On the development of the first Salpausselkä west of Lahti. Bulletin de la Commission géologique de Finlande 202, 162 p.

Окко, Veikко (1949) The general geological map of Finland. Sheet B 4, Kokkola. Explanation to the map of surficial deposits. The Geological Survey of Finland, $55 \mathrm{p}$.

- (1964) Maaperä. Suomen geologia, toim. K. Rankama, Helsinki, pp. 239-332.

Pentrilä, Seppo (1963) The deglaciation of the Laanila area, Finnish Lapland. Bulletin de la Commission géologique de Finlande 203, 71 p.

Ramsay, Wilhelm (1900) Über die geologische Entwicklung der Halbinsel Kola in der Quartärzeit. Fennia 16, 1, $151 \mathrm{p}$.

- (1912) Über die Verbreitung von Nephelinsyenitgeschieben und die Ausbreitung des nordeuropäischen Inlandeises im nördlichen Russland. Fennia 33, 1, $17 \mathrm{p}$.

Rasmussen, H. Wienberg (1968) Danmarks geologi, København, 176 p. 
REPO, RerNo (1957) Untersuchungen über die Bewegungen des Inlandeises in Nordkarelien. Bulletin de la Commission géologique de Finlande 179, 178 p.

- (1964) Observations on the Jyväskylä ice-marginal formation in central Finland. Bulletin de la Commission géologique de Finlande 215, pp. 147-162.

- (1969) Geological map of Finland 1: 100 000. Sheet 4223, Joensuu. Explanation to the map of superficial deposits. The Geological Survey of Finland, 86 p.

- (1970) Geological map of Finland 1: 100 000. Sheet 2032, Espoo. Explanation to the map of Quaternary deposits. The Geological Survey of Finland, 35 p.

Repo, Reino und Trnni, Risto (1967) Zur spät- und postgalzialen Entwicklung im Ostteil des ersten Salpausselkä. Comptes Rendus de la Société géologique de Finlande No. XXXIX, pp. 133-159.

- (1969) Morphologisch-stratigraphische Gundzüge des östlichen Salpausselkä-Gebiets. Bulletin of the Geological Society of Finland 41, pp. 203-229.

Rosberg, J. E. (1892) Ytbildningar i ryska och finska Karelen med särskild hänsyn till de karelska randmoränerna. (Referat). Oberflächenbildungen im russischen und finnischen Karelen mit besonderer $\mathrm{Be}$ rücksichtigung der karelischen Randmoränen. Fennia $7,2,128 \mathrm{p}$

Saksela, Martti (1949) Das pyroklastische Gestein von Lappajärvi und seine Verbreitung als Geschiebe. Bulletin de la Commission géologique de Finlande 144, pp. $19-30$.

Sauramo, Matri (1918) Geochronologische Studien über die Spätglazialzeit in Südfinnland. Bulletin de la Commission géologique de Finlande 50, 44 p.

- (1924) Tracing of glacial boulders and its application in prospecting. Bulletin de la Commission géologique de Finlande 67, 37 p.

- (1924) Suomen geologinen yleiskartta. Lehti B 2, Tampere. Maalajikartan selitys. Suomen geologinen Komissioni, 76 p.

- (1927) Suomen geologinen yleiskartta. Lehti C 4, Kajaani. Maalajikartan selitys. Suomen geologinen toimikunta, $80 \mathrm{p}$.

- (1929) The Quaternary geology of Finland. Bulletin de la Commission géologique de Finlande 86, 110 p.

Sederholm, J. J. (1889) Om istidens bildningar i det inre af Finland. (Auszug). Ueber die Bildungen der Eiszeit im inneren Finnland. Fennia 1, 7, 52 p.

TANner, V. (1915) Studier öfver kvartärsystemet i Fennoskandias nordliga delar III. Om landisens rörelser och afsmältning i Finska Lappland och angränsande trakter. Résumé. Fennia 36, 815 p.
Tynni, Risto (1969) Geological map of Finland $1: 100$ 000. Sheet 2044, Riihimäki. Explanatory text to the map of Quaternary deposits. The Geological Survey of Finland, 95 p.

Winterhalter, Boris (1972) On the geology of the Bothnian Sea, an epeiric sea that has undergone Pleistocene glaciation. Geological Survey of Finland, Bulletin 258, 66 p.

VirkKalA, K. (1949) The general geological map of Finland. Sheet D 4, Nurmes. Explanation to the map of superficial deposits. The Geological Survey of Finland, 54 p.

- (1951) Glacial geology of the Suomussalmi area, East Finland. Helsinki, 66 p.

- (1954) Suomen geologinen kartta 1: 100000 . Lehti 4422, Suomussalmi. Maaperäkartan selitys. Geologinen tutkimuslaitos, $48 \mathrm{p}$.

- (1959) The general geological map of Finland $1: 100$ 000, Sheet 2043, Kerava. Explanation to the map of superficial deposits. The Geological Survey of Finland, 99 p.

- (1959) Rauman seudun luonnonsuhteista ja geologisesta kehityksestä. Rauma, 18 p.

- (1960) On the striations and glacier movements in the Tampere region, Southern Finland. Bulletin de la Commission géologique de Finlande 188, pp. 158 176.

- (1960) Geological map of Finland $1: 100000$. Sheets 4421, 4422, 4423 - 4441, 4424, Hyrynsalmi, Suomussalmi, Vuokkijärvi, Raate. Explanation to the map of superficial deposits. The Geological Survey of Finland, $62 \mathrm{p}$.

- (1961) On the glacial geology of the Hämeenlinna region, Southern Finland. Bulletin de la Commission géologique de Finlande 196, pp. 215-241.

- (1962) Geological map of Finland 1: 100 000. Sheet 2123, Tampere. Explanation to the map of superficial deposits. The Geological Survey of Finland, $70 \mathrm{p}$.

- (1963) On ice-marginal features in Southwestern Finland. Bulletin de la Commission géologique de Finlande 210, 76 p.

- (1969) Geological map of Finland 1: 100 000. Sheet 2131, Hämeenlinna. Explanation to the map of Quaternary deposits. The Geological Survey of Finland, 69 p.

Manuscript received, April 27, 1973. 